\title{
DIVERSITATEA FAUNEI DE VERTEBRATE TERESTRE DIN REZERVATIIA „PRUTUL DE JOS” REPUBLICA MOLDOVA
}

\author{
Paladi Viorica ${ }^{1}$, Nistreanu Victoria ${ }^{2}$ \\ ${ }^{1}$ Rezervația "Prutul de Jos", Republica Moldova, vioricapaladi.c@gmail.com \\ ${ }^{2}$ Institutul de Zoologie, Chișinău, Republica Moldovei \\ vicnistreanu@gmail.com
}

https://doi.org/10.53937/9789975315975.18

Rezervația „Prutul de Jos" este situată în partea de sud-vest a Republicii Moldova, de-a lungul cursului inferior al râului Prut. Suprafaţa totală a rezervaţiei este de 1755,4 ha, dintre care: pășuni - 124, păduri - 366, luncă inundabilă - 610, alunecări de teren - 4,4, alte terenuri - 23 ha. Lacul Beleu are o suprafaţă de 628 ha și este un relict al Limanului Dunărean de apă dulce. Este un monument al naturii de mare valoare știinţifică, culturală și estetică cu dimensiunile: lăţime - $2 \mathrm{~km}$, lungime - $5 \mathrm{~km}$, adâncime medie 0,5-1,5 m, adâncime maximă - 4,2 m. În cadrul rezervaţiei a fost delimitată Zona cu protecţie integrală pe o suprafaţă de 168,3 ha - un teritoriu unic unde s-au păstrat complexe floristice și faunistice specifice și caracteristice ecosistemelor acva-palustre.

Cercetările multianuale efectuate în zonă au relevat existența unei diversități mari a faunei de vertebrate terestre, cuprinzând 40 specii de mamifere, 192 specii de păsări, 7 specii de reptile și 9 specii de amfibieni (Andreev ș.a., 2012; Postolache ș.a., 2012; Paladi, 2013). Studiile din ultimii ani au permis completarea listelor faunistice ale mamiferelor și păsărilor.

Mamiferele de pe teritoriul rezervației și din zonele limitrofe sunt reprezentate de 44 specii din 6 ordine: Insectivora - 7, Chiroptera - 8, Lagomorpha - 1, Rodentia - 16, Carnivora - 11 și Artiodactyla - 2 specii. Dintre speciile identificate 15 sunt incluse în Cartea Roșie a Republicii Moldova (2015), iar vidra (Lutra lutra) și nurca europeană (Mustela lutreola) sunt specii de importanţă conservativă internaţională, fiind incluse 
în Lista Roșie a IUCN și în Convenţia Berna (Anexa II). Prezenţa nurcii europene în cursul inferior al Prutului se datorează migraţiei din Delta Dunării, iar efectivul reproductiv al acesteia se află la limita critică. Toate speciile de lilieci sunt incluse în Anexa II a Convenției de la Bonn privind protecția speciilor migratoare.

Teritoriul rezervației și sectoarele adiacente fac parte dintr-un important traseu de migraţie, iar bazinele acvatice și vegetația specifică creează condiţiile favorabile de hrănă, reproducere, popas și iernare pentru 196 specii de păsări din 17 ordine. Au fost identificate 7 tipuri zoogeografice: siberian, arctic, mongol, transpalearctic, european, chinez și mediteranean. Pentru speciile acvatice neclocitoare sunt dominante tipurile zoogeografice nordic, siberian (21\%), mongol (20\%) și arctic (16\%), specifice unui climat rece și mai arid. Celelalte două tipuri zoogeografice - transpalearctic (16\%) și european (11\%) au o pondere mai mică. Printre speciile clocitoare dominante sunt tipurile: transpalearctic (18\%), european, mediteranean, mongol și chinez cu doar 2\%. Dintre cele 17 ordine ale avifaunei ponderea cea mai mare o are ordinul Passeriformes cu 60 de specii, urmat de ordinele Charadriiformes, Anseriformes și Falconiformes. În perioada migraţiei de primăvară și toamnă pot fi observate mii de păsări, dintre acestea multe fiind rare pe plan european sau chiar mondial. În componența avifaunei 6 specii sunt incluse în Lista Roșie a IUCN: gâsca cu gât roșu (Branta ruficollis), gârliţa mică (Anser erythropus), raţa roșie (Aythya nyroca), cresteiul de câmp (Crex crex), cormoranul mic (Phalacrocorax pygmeus), raţa cu cap alb (Oxyura leucocephala); 22 specii sunt incluse în lista SPEC (Species of Conservaţions Concern); 35 specii sunt liatete în cartea Roșie a Republicii Moldova: cormoranul mic (Phalacrocorax pygmeus), pelicanul comun (Pelecanus onocrotalus), lopătarul (Platalea leucorodia), vulturul codalb (Haliaeetus albicilla), egreta mare (Egretta alba), stârcul galben (Ardeola ralloides), barza neagră (Ciconia nigra), țigănușul (Plegadis falcinellus), lebăda de vară (Cygnus olor), lebăda de iarnă (C. cygnus) etc. În ultimii ani se re- 
marcă apariţia sutelor, uneori miilor de exemplare ale pelicanului comun (P. onocrotalus), care poposesc doar pentru hrană și repaus preponderent în lunile de vară, când nivelul apei în lac este foarte scăzut. Speciile care cuibăresc cel mai frecvent sunt stârcul galben (Ardeola ralloides), egreta mică (Egretta garzetta), stârcul cenușiu (Ardea cinerea), lopătarul (Platalea leucorodia), stârcul-de-noapte (Nycticorax nicticorax), urmate de egreta mare (Casmerodius albus), ţigănușul (Plegadis falcinellus), cormoranul mic (Ph. pygmaeus) cormoranul mare (Ph. carbo) și stârcul roșu (A. purpurea). Printre reprezentanţii ordinelor falconiforme și strigiforme au fost înregistrați codalbul (Haliaëtus albicilla), acvila de câmp (Aquila heliaca), acvila ţipătoare mică (A. pomarina), șoricarul comun (Buteo buteo), uliul păsărar (Accipiter nisus), gaia roșie (Milvus milvus), gaia neagră (M. migrans), uliganul pescar (Pandion haliaetus), eretele de stuf (Circus aieruginosus), ciuful de câmp (Asio flammeus) etc.

Dintre reptile au fost înregistrate 7 specii: șopârla ageră (Lacerta agilis), șopârla verde (L. viridis), șopârla de Crimeea (Podarcis taurica), șarpele de casă (Natrix natrix), șarpele de apă (N. tessellata), broasca ţestoasă de baltă (Emys orbicularis) și șarpele cu abdomen galben (Coluber jugularis), care populează un teritoriu limitat din zona protejată a rezervaţiei. Amfibienii au condiţii favorabile de hrănire și reproducere pe întreg teritoriul, fiind prezente 9 specii sau 69,2\% din numărul total de amfibieni din republică. În Cartea Roșie a Moldovei sunt incluse 3 specii de reptile și 6 specii de amfibieni.

Rezervaţia „Prutul de Jos" constituie un muzeu al biodiversităţii, o bancă de gene naturală de valoare inestimabilă pentru patrimoniul natural naţional și cel universal, iar studiile vor continua.

Studiile au fost efectuate în cadrul proiectului fundamental 15.187.0211F 